\title{
WHY SEXUAL ABUSE? AN EXPLORATION OF THE INTERGENERATIONAL HYPOTHESIS
}

\author{
KathleEn COUlborn Faller
}

University of Michigan School of Social Work, Ann Arbor

\begin{abstract}
The issue of sexual abuse in the family backgrounds of offenders and mothers of victims is explored in a clinical sample of 154 cases of intrafamilial sexual abuse. More than a third of the offenders and about half of the mothers had experienced or been exposed to sexual abuse as children. Cases were divided into those where the sexual abuser was the biological father in an intact family, those where he was a stepfather or mother's live-in partner, and those where he was a noncustodial father. In biological father cases, parents were about equally likely to have experienced sexual abuse during childhood, in the stepfather/live-in partner cases, the mother was more likely to have had such an experience, and in the noncustodial father cases, the offender was more likely to have come from a sexually abusive family.
\end{abstract}

NO DOUBT MULTIPLE FACTORS contribute to cause child sexual abuse, and these vary depending upon the case. However, one of the predisposing conditions that has been of considerable interest to clinicians and researchers is an experience of sexual abuse in childhood (Abel et al., 1984; Finkelhor, 1986; Gebhard, Gagnon, Pomeroy, \& Christensen, 1965; Greenberg, 1978; Groth, 1979; Groth \& Burgess, 1979; Longo, 1983; Mayer, 1985; Seghorn, Boucher, \& Prentky, n.d.). (See Finkelhor, 1984, for a comprehensive discussion of the causes of sexual abuse.) Being sexually victimized as a child is a common experience for adult sex offenders (Abel et al., 1984; Gebhard et al., 1965; Greenberg, 1978; Groth, 1979; Longo, 1983; Mayer, 1985; Seghorn et al., n.d.) and mothers of victims of sexual maltreatment (Goodwin, McCarty, \& Divasto, 1982; Mayer, 1983; Meiselman, 1978; Mrazek, 1981; Renshaw, 1982; Rosenfeld, 1979; Summit \& Kryso, 1978; Weiner, 1964). Moreover, childhood experiences of sexual abuse have been found at higher rates among those who victimize or are mothers of victims than in comparison groups (Gebhard et al., 1965; Goodwin et al., 1982; Groth \& Burgess, 1979).

This study examined sexual abuse in the family of origin in a clinical sample of intrafamilial sexual abuse cases. Of interest were the occurrences of victimization in the backgrounds of both mothers of victims and offenders.

\section{METHOD}

The sample consisted of 154 cases of intrafamilial sexual abuse seen by staff from the University of Michigan Interdisciplinary Project on Child Abuse and Neglect (IPCAN) between the years 1978 and 1986. (IPCAN is a project composed of faculty who teach, train, practice,

Received for publication March 11, 1988; final revision received February 2, 1989; accepted February 8, 1989.

Reprint requests may be sent to Kathleen Coulborn Faller, M.S.W., Ph.D., University of Michigan School of Social Work, 1065 Frieze Building, Ann Arbor, MI 48109. 
and conduct research in child maltreatment.) This study sample was a subset of a larger sample of 375 cases and consisted of all validated sexual abuse cases where, at the time of the abuse, the offender was a biological father of the victim, married to the mother; a stepfather; a live-in boyfriend of the mother; or a noncustodial father. (For a description of the validation process, see Faller, 1988.) These cases were selected because the goal of the research was to study variability in sexual abuse by paternal caretakers. Although the cases were seen primarily for diagnosis, case management recommendations, and/or treatment, data were systematically collected for research purposes.

Of the subset of cases described here, $74 \%$ were referred by county-based child protection agencies, $10.6 \%$ by the courts, $6.4 \%$ by law enforcement agencies, and $9 \%$ by other mental health agencies. Data were collected during the course of clinical interviews lasting from 2 to 15 hours (mean $=5.7$ hours).

The 154 cases discussed in this article can be divided into 3 subgroups: 55 cases where the perpetrator was the child's biological father, married to and living with the mother; 56 cases where the perpetrator was a stepfather or live-in boyfriend (LTP) (38 stepfathers and 18 livein partners were combined because clinical dynamics and characteristics of sexual abuse in family of origin were similar); and 43 cases where the perpetrator was the biological father, but separated or divorced from the mother who was the custodial parent, the sexual abuse usually occurring on visitation. (This number was smaller than those for the other two groups because of the difficulty in validating these cases.)

To gather data about sexual abuse in the parents' families of origin, information was collected from the mother, the perpetrator, the victim, and other agencies and their records. In addition, occasionally information was provided by significant others, such as a grandmother or a family friend. Mothers were asked about their own experiences and those of the perpetrators and vice versa.

Sexual abuse in the family of origin was categorized for both the mother and the offender as follows: 1 = yes (sexual abuse found); $2=$ no (no sexual abuse found); $3=$ no information. The parental figure's sexually abusive experience could have been by a parent, a relative, or a nonrelative. Attempts to differentiate the relationship and sex of the perpetrator to the victimparent were abandoned because the numbers in each group were too small. In addition, because there is considerable evidence that sexual abuse is transmitted intergenerationally by means of modeling as well as by being abused, the parent did not have to actually be a victim, but could be coded as having sexual abuse in the family of origin if a sibling had been sexually abused by a relative or a parent had sexually abused a child outside the home (Adams, Tollison, \& Carson, 1981; Calhoun \& Turner, 1981; Rosenthal, 1976; Tollison \& Adams, 1979).

The definition of sexual abuse excluded noncontact behaviors, such as sexually suggestive talk, exposure, and voyeurism, and the perpetrator had to have been at least five years older than the victim. Cases categorized as "no information" were those where data could not be obtained. An example of the latter might be a situation where the perpetrator refused to be interviewed, and there was no information from other sources indicating whether hc had or had not experienced sexual abuse in his childhood.

\section{RESULTS}

Data is presented for the sample as a whole and for the three subgroups of paternal caretakers. The distribution of findings for the 154 cases appears in Table 1 . The data indicate mothers were more likely than offenders to have experienced sexual abuse, almost half having had sexually abusive experiences as children. For the 76 mothers reporting sexual abuse, 65 directly experienced victimization; whereas of the 61 men reporting sexual abuse, only 31 were 
Table 1. Sexual Abuse in Families of Origin

\begin{tabular}{llllll}
\hline & \multicolumn{2}{c}{$\begin{array}{c}\text { Mother's } \\
\text { Background }\end{array}$} & & \multicolumn{2}{c}{$\begin{array}{c}\text { Offender's } \\
\text { Background }\end{array}$} \\
\cline { 2 - 3 } \cline { 5 - 6 } Sexual Abuse & No. & $\%$ & & No. & $\%$ \\
\hline 1. Yes & 76 & 49.4 & & 61 & $39.6^{*}$ \\
2. No & 54 & 35.1 & & 55 & 35.7 \\
3. No information & 24 & 15.6 & & 38 & 24.7 \\
\hline $\mathrm{n}=154$ & & & & & \\
* In 20 cases sexual abuse was found in both the mother's and the offender's family \\
of origin.
\end{tabular}

victims $\left(\chi^{2}=24.2 ; p<.0000\right)$. This is not surprising since women are 2 to 10 times more likely to be sex abuse victims than men. When cases where there was no information were eliminated, $59 \%$ of women had sexual victimization in their backgrounds. Sexual abuse was found in the father figure's background less frequently but nevertheless in almost $40 \%$ of cases. The percentage for paternal figures increased to $53 \%$ when cases with no information were eliminated. In 20 cases (13.8\%), both parents experienced sexual abuse in their childhood, and a little more than a third of both mothers and offenders denied sexual abuse.

When the experiences of mothers and father figures in the three subgroups included in this sample were examined separately, the results were quite interesting. They appear in Tables 2 and 3.

There were statistically significant differences among the three types of cases in terms of the kind of family of origin sexual abuse. As indicated in Tables 2 and 3, in the bio-father cases either parent might have experienced sexual abuse, and the findings generally paralleled those for the sample as a whole; however, the results for the stepfather-LTP and noncustodial father groups were quite divergent. In stepfather-LTP cases, it was the mother who was likely to have experienced sexual abuse, victimization being reported in more than two-thirds of cases. Of mothers in the stepfather-LTP group who reported sexual abusc in their childhoods, 34 $(87.2 \%)$ were actually victims. In contrast, in the noncustodial father subgroup, it was the father, in more than two-thirds of cases, who was exposed to abuse or victimized as a child. Of the noncustodial fathers with sexual abuse in their backgrounds, $12(40 \%)$ were actual victims.

Scxual abuse in the backgrounds of both parents was found in a comparable proportion for the three subgroups (biofather $=40 \%$; stepfather-LTP $=30 \%$; noncustodial father $=30 \%$ ). When the three groups were compared as to whether there was any versus no sexual abuse reported in families of origin, the difference was not statistically significant $\left(\chi^{2}=.20 ; p=.90\right)$.

Table 2. Sexual Abuse in Mothers' Families of Origin in Three Paternal Caretaker Situations

\begin{tabular}{|c|c|c|c|c|c|c|}
\hline \multirow[b]{2}{*}{ Sexual Abuse } & \multicolumn{2}{|c|}{ Biofather } & \multicolumn{2}{|c|}{ Stepfather LTP } & \multicolumn{2}{|c|}{$\begin{array}{l}\text { Non-custodial } \\
\text { Father }\end{array}$} \\
\hline & No. & $\mathrm{C} \% *$ & No. & $\mathrm{C} \%$ & No. & $\mathrm{C} \%$ \\
\hline 1. Yes & 27 & 49.1 & 39 & 69.6 & 10 & 23.3 \\
\hline 2. No & 21 & 38.2 & 8 & 14.3 & 25 & 58.1 \\
\hline 3. No information & 7 & 12.7 & 9 & 16.1 & 8 & 18.6 \\
\hline
\end{tabular}

Chi square $=24.7 ; p<.0000 ; d f=4 ; n=154$.

* $\mathrm{C} \%=$ column percentage. 
Table 3. Sexual Abuse in Offenders' Families of Origin for Three Paternal Caretaker Situations

\begin{tabular}{|c|c|c|c|c|c|c|}
\hline \multirow[b]{2}{*}{ Sexual Abuse } & \multicolumn{2}{|c|}{ Biofather } & \multicolumn{2}{|c|}{ Stepfather LTP } & \multicolumn{2}{|c|}{$\begin{array}{l}\text { Non-custodial } \\
\text { Father }\end{array}$} \\
\hline & No. & $\mathrm{C} \% *$ & No. & $\mathrm{C} \%$ & No. & $\mathrm{C} \%$ \\
\hline 1. Yes & 21 & 38.2 & 10 & 17.9 & 30 & 69.8 \\
\hline 2. No & 15 & 27.3 & 33 & 58.9 & 7 & 16.3 \\
\hline 3. No information & 19 & 34.5 & 13 & 23.2 & 6 & 14.0 \\
\hline
\end{tabular}

Chi square $=34.9: p<.0000 ; d f=4: N=154$.

$* \mathrm{C} \%=$ column percentage

\section{DISCUSSION}

Based upon the high percentages of parents in the sample as a whole who had an experience with sexual abuse in their childhood, sexual abuse in the family of origin seems a fruitful avenue to pursue for understanding why intrafamilial sexual abuse occurs. Almost $40 \%$ of the abusers and almost half of the victims' mothers reported sexual abuse in their childhood. Rates of sexual victimization reported in the general population vary depending upon the definition of victimization, data collection methods, and sample sources, but average about $21 \%$ for women and $7 \%$ for men (Finkelhor, 1986).

Furthermore, rates for both perpetrators and mothers were probably underestimates. First, there were some missing data, information being unavailable for about $15 \%$ of mothers and close to a quarter of offenders. Second, there is considerable clinical evidence that traumatic events such as being sexually abused are often repressed and therefore might well not have been recalled, especially during the course of a single two- or three-hour interview. Third, these adults may have chosen, for a variety of reasons, to deny their abuse.

Perhaps more intriguing were the differences found in parental victimization for the three subgroups. The data might be interpreted as indicating that when the abuser was a biological father in an intact family, the childhood experiences of either parent could play a role in causing the sexual victimization of the children. However, when the abuser was a stepparent or mother's live-in boyfriend, the mother's victimization or exposure to sexual abuse as a child appeared to play a crucial role. On the other hand, when the perpetrator was a noncustodial father, it was his childhood sexual experience that was pivotal in his sexually abusing his child.

It is difficult to know exactly how these respective sexual experiences operate. However, clinical information from the subgroups may be helpful in interpretation. Taking first the stepfather-LTP cases, instructive patterns can be found in these families before the stepfathers or boyfriends became involved. Close to one-third of the biological fathers in these cases had also sexually abused their children, and more than half had physically abused the mother or children. Yet mothers, having extricated themselves from those relationships, developed subsequent ones with men having comparable problems. Perhaps mothers in the stepfather group chose that which was familiar and consistent with their model of masculinity, and thus selected men like their own abusers and their children's previous abusers. In addition, because of their childhood victimization, they may gravitate toward men who will not make sexual demands upon them (Briere, 1984; Browne \& Finkelhor, 1986; Courtois, 1979; Herman, 1981; Meiselman, 1978) because the men's real interest is in children. Furthermore, because of their own vulnerability resulting from past exploitation, they do not perceive that they put their children in situations where they are at risk when they introduce these men into the home. However, it would be erroneous to attribute too much weight to the mother's child- 
hood experience. Rates of sexual abuse are much higher in stepfamilies than in bio-families (Finkelhor \& Brown, 1986; Russell, 1984). Structural factors such as the ahsence of the incest taboo also play an important role.

In noncustodial father cases, while it might be argued that the stress of marital break-up, and in some instances, consequent anomie were important factors in the sexual abuse, in all but three cases there was evidence prior to the marital demise of the propensity to sexually abuse. While in only two cases was actual sexual abuse documented during the marriage, there were worrisome incidents and behaviors, such as the father teaching the victims to French kiss, the father bathing the child and experiencing an erection, the father engaging in an unusual amount of sensual physical contact with the child, and the father sleeping with the child in the mother's absence. Thus, arguably, based upon their childhood experiences, these fathers were sexually attracted to children; however, these feelings were held in check until the marital dissolution, when loneliness and unsupervised access to the children facilitated their expression. In addition, the exposure to sexual abuse that more than half of these men had experienced in childhood was their fathers, stepfathers, or other male relatives sexually abusing siblings and sometimes other children. In such instances, sexually abusive behavior may reflect the effect of modeling.

\section{CONCLUSION}

The existence of sexual abuse in parental families of origin appears to hold promise for understanding intrafamilial sexual abuse. Furthermore, examining subgroups of this population may help to refine our understanding of how such sexual experiences operate in different circumstances. However, the results of this study must be accepted with caution. This was a clinical sample and not necessarily representative of sexual abuse dynamics in a nonclinical population. Moreover, there was no control or comparison group. Finally, intergenerational factors certainly do not operate in isolation to cause sexual abuse (Finkelhor, 1986). Nevertheless, they should be the focus of continued exploration because, unlike many other causal factors (e.g., a culture sanctioning male dominance, sexual orientation), they are treatable using existing mental health technologies. Such intervention can be both preventative and palliative.

\section{REFERENCES}

Abel, G., Becker, J. V., Cunningham-Rathner, J., Renlean, J., Kaplan, M., \& Reid, J. (1984). The treatment of child molesters. Unpublished manuscript. Sexual Behavior Clinic, New York.

Adams, H., Tollison, D., \& Carson, T. (1981). Behavior therapy with sexual deviations. In S. Turner, K. Calhoun \& H. Adams (Eds.), Handbook of clinical behavior therapy. New York: John Wiley and Sons.

Briere, J. (1984). The long-term effects of sexual victimization: Defining the post-sexual abuse syndrome. Paper presented at the National Conference on Sexual Victimization of Children, Washington, DC.

Browne, A., \& Finkelhor, D. (1986). Initial and long-term effects: A review of the research. In D. Finkelhor (Ed.), Sourcebook on Child Sexual Abuse. Beverly Hills: Sage.

Calhoun, K., \& Turner, S. (1981). Historical perspectives and current issues in behavior therapy. In S. Turner, K. Calhoun, \& H. Adams, (Eds.), Handbook of clinical behavior therapy. New York: John Wiley and Sons.

Courtois, C. (1979). Incest experience and its aftermath. Victimology, 4, 337-347.

Faller, K. C. (1988). Child sexual abuse: An interdisciplinary manual for diagnosis, case management, and treatment. New York: Columbia University Press.

Finkelhor, D. (1984). Child sexual abuse: New concepts and research. New York: Free Press.

Finkelhor, D. (Ed.). (1986). Sourcebook on child sexual abuse. Beverly Hills, CA: Sage.

Finkelhor, D., \& Brown, L. (1986). High risk children. In D. Finkelhor (Ed.), Sourcebook on child sexual abuse. Beverly Hills, CA: Sage. 
Gebhard, P., Gagnon, J., Pomeroy, W., \& Christensen, C. (1965). Sex offenders: An analysis of types. New York: Harper and Row.

Goodwin, J., McCarty, T., \& Divasto, P. (1982). Physical and sexual abuse of children of adult incest victirns. In $\mathbf{J}$. Goodwin, (Ed.), Sexual abuse: Incest victims and their families. Boston: John Wright PSG.

Greenberg, N. (1978, September). The traumatic characteristics of childhood sexual abuse. Paper presented at the Second International Congress on Child Abuse and Neglect, I ondon.

Groth, N. (1979). Men who rape. New York: Plenum.

Groth, N., \& Burgess, A. (1979). Sexual trauma in the lives of rapists and child molesters. Victimology, 4, 10-16.

Herman, J. (1981). Father-daughter incest. Boston: Cambridge University Press.

Longo, R. (1983). Administering a comprehensive treatment program in a maximum security setting. In J. Greer \& I. Stuart (Eds.), The sexual aggressor. New York: Van Nostrand Reinhold.

Mayer, A. (1983). Incest: A treatment manual for victims, spouses, and offenders. Holmes Beach, FL: The Learning Press.

Mayer, A. (1985). Sexual abuse: Causes, consequences, and treatment of incestuous and pedophilic acts. Holmes Beach, FL: The Learning Press.

Meiselman. K. (1978). Incest. San Francisco: Jossey-Bass.

Mrazek, P. (1981). Definition and recognition of child sexual abuse: Historical and cultural perspectives. In P. Mrazek \& C. H. Kempe (Eds.), Sexually abused children and their families. London: Pergamon.

Renshaw, D. (1982). Incest: Understanding and treatment. Boston: Little, Brown.

Rosenfeld, A. A. (1979). Endogamic incest and the victim-perpetrator model. American Journal of Disabled Children, 133, 406-410.

Rosenthal, T. M. Modeling therapies. (1976). In M. Hersen, R. M. Eisler, and P. M. Miller (Eds.), Progress in behavior modification (Vol. 12). New York: Academic Press.

Russell, D. (1984). The prevalence and seriousness of incestuous abuse: Stepfathers versus biological fathers. Child Abuse \& Neglect, 8(1), 15-22.

Seghorn, T., Boucher, R. J., \& Prentky, R. A. (n.d.). Childhood sexual abuse in the lives of sexually aggressive offenders. Unpublished manuscript. Bridgewater, Massachusetts Treatment Center.

Summit, R., \& Kryso, J. (1978). Sexual abuse of children: A clinical spectrum. American Journal of Orthopsychiatry, 48(2), 237.251.

Tollison, C. D., \& Adams, H. (1979). Sexual disorders: Treatment, theory, and research. New York: Gardner.

Weiner, I. (1964). On incest: A survey. Etcerpta Criminologica, 4, 4-9.

Résumé-L'auteur a exploré, dans un collectif de 154 cas de sévices sexuels intra-familiaux, l'anamnèse familiale quant aux abus sexuels subis par les auteurs et les mères des victimes eux-mêmes. Plus d'un tiers des agresseurs et environ la moitié des mères des victimes avaient subi des violences sexuelles dans leur enfance. Les cas étaient divisés en 3 groupes: un groupe où l'agresseur sexuel était le père biologique dans une famille intacte; un deuxième groupe où l'agresseur était un beau-père ou un compagnon de la mère et enfin un groupe où l'agresseur était un père qui n'avait pas la garde de l'enfant. Lorsque l'agresseur était le pèré biologique, les 2 parents a vaient également été soumis à des sévices sexuels pendant l'enfance. Lorsque l'agresseur était un beau-père qui vivait avec la mère, c’était le plus souvent la mère qui avait subi les sévices sexuels et dans le cas d'un père qui n'avait pas la garde de l'enfant, l'agresseur était le plus souvent issu d'une famille où l'on avait connu des sévices sexuels.

Resumen-El problema del abuso sexual en los antecedentes familiares de los perpetradores y las madres de las victimas es explorado en una muestra clinica 154 casos de abuso sexual intrafamilar. Más de una tercera parte de los perpetradores y cerca de la mitad de las madres habian experimentado o sido expuestos al abuso sexual cuando niños. Los casos fueron divididos en aquellos en que el abusador sexual fué el padre biológico en una familia intacta, aquellos en que lo fué el padrastro o la pareja casera de la madre, y aquellos en que lo fué un padre que no tenía custodia del menor. En los casos en que el perpetrador fué el padre biológico, ambos padres tenían la misma probabilidad de haber experimentado abuso sexual durante su niñez, en los casos en que los perpetradores fueron los padrastros o parejas caseras, la madre tenía más probabilidad de haber sido abusada, y en los casos en que los perpetradores eran los padres que no tenían custodia, el perpetrador tenía más probabilidad de venir de una familia sexualmente abusiva. 